\title{
PATENTS: SUPREME COURT HOLDS POST-EXPIRATION ROYALTY AGREEMENTS UNLAWFUL PER SE
}

A patent confers upon the patentee the exclusive right to preclude others from making, using or selling the invention embodied in the patent for a term of seventeen years. ${ }^{1}$ The patentee, however, may grant to others the right to make, use and/or sell; ${ }^{2}$ he usually does so through licensing agreements which exact royalties for those rights. This practice has been limited by the United States Supreme Court in Brulotte v. Thys Co., ${ }^{3}$ which held that "use of a royalty agreement that projects beyond the expiration of the patent is unlawful per se."4

The plaintiff in Brulotte owned various patents for hop-picking, and sold machines embodying many of those patents pursuant to sale and license agreements. These agreements passed "title" to the machines at a flat sum, and licensed their use in return for royalties computed either on the basis of a fixed sum per hop-picking season or a fixed rate per unit of hops picked, whichever was greater. The licenses were to extend for a term of seventeen years and further required that the licensee not assign his interest or remove the machine from the county of sale without the permission of the licensor. Defendants Brulotte and Charvet were obligated under the licenses to pay royalties through the 1958 and 1960 harvest seasons respectively. Only seven of the twelve patents listed in the licenses were incorporated into the machines; those seven patents all expired on or before 1957. The other five patents, which were for improvement devices available for use but not actually used on defendants' machines, expired on or before $19600^{5}$

When the defendants refused to pay royalties accruing after 1952, the plaintiff recovered a judgment in the Washington state courts. The supreme court of that state affirmed, holding that a

\footnotetext{
${ }^{2}$ See Patent Code of 1952, $\$ 154,35$ U.S.C. $\$ 154$ (1964). The Patent Code implements U.S. Const. art. I, §8. See generally Andur, Patent Law and Practice (1935); Stedman, Patents (1939); Walker, Patents (Deller ed. 1937, Supp. 1964).

${ }^{2}$ See, e.g., Adams v. Burke, 84 U.S. (17 Wall.) 453, 456 (1873).

s 379 U.S. 29 (1964), petitions for rehearing and for clarification denied, 379 U.S. 985 (1965).

Idd. at 32.

- Brief for the United States as Amicus Curiae, pp. 3.6; Brief for Petitioners, pp. 2-9; Brief for Respondent, pp. 1-6.
} 
seventeen-year period was a reasonable amount of time over which to spread payments for the use of a patent. ${ }^{\circ}$ The Supreme Court reversed, disallowing royalties accruing after 1957, the date of expiration for the most recent patent actually used in the machines. ${ }^{7}$

The enforceability of royalty agreements extending beyond the expiration date of a patent has had a history of uncertainty. Beginning in 1901, a series of decisions in the Second Circuit announced in dictum the rule that royalties may not accrue after expiration except when parties expressly contract to the countrary. ${ }^{8}$ This rule was perpetuated by lower federal court and state supreme court decisions, ${ }^{\theta}$ and in only a few of those decisions did the royalty agreements fall within the contractual exception. ${ }^{10}$ The rule had been adopted unequivocally by all treatises ${ }^{11}$ dealing with the subject, and it seems clear that it has been relied upon often by parties preparing royalty agreements. ${ }^{12}$

Simultaneous with the development of the rule permitting express post-expiration royalty agreements, however, has been the evolution of the doctrine of patent misuse. That doctrine, supposedly the patent equivalent of the equitable rule of "unclean hands,"13 denies judicial relief to a patentee who engages in activity

\footnotetext{
'Thys Co. v. Brulotte, 62 Wash. 2d 284, 382 P.2d 271 (1963), rev'd, 379 U.S. 29 (1964).

7379 U.S. at 30 .

${ }^{8}$ E. R. Squibb \& Sons v. Chemical Foundation, Inc., 93 F.2d 475, 477 (2d Cir. 1937) (dictum); Pressed Steel Car Co. v. Union Pac. R.R., 270 Fed. 518, 525 (2d Cir. 1920) (dictum); Sproull v. Pratt \&. Whitney Co., 108 Fed. 963, 965 (2d Cir. 1901) (dictum).

${ }^{\circ}$ See, e.g., Tate v. Lewis, 127 F. Supp. 105 (D. Mass. 1954); H-P-M Dev. Corp. v. Watson-Stillman Co., 71 F. Supp. 906 (D.N.J. 1947); Six Star Lubricants Co. v. Morehouse, 101 Colo. 391, 74 P.2d 1239 .(1937); Mcleod v. Crawford, 176 Neb. 513, 126 N.W.2d 663 (1964).

${ }^{10}$ Well Surveys, Inc. v. McCullough Tool Co., 199 F. Supp. 374 (N.D. Okla. 1961), aff'd, 343 F.2d 381 (10th Cir. 1965); Adams v. Dyer, 129 Cal. App. 2d 160, 276 P.2d 186 (1954); Six Star Lubicants Co. v. Morehouse, supra note 9; McLeod v. Crawford, supra note 9 .

11 See, e.g., 69 C.J.S. Patents $\$ \$ 252,262$ (1951); Ellis, Patent Licenses $\$ 109$ (2d ed. 1958).

${ }^{12}$ This is suggested, for example, by the Brief for Wells Surveys, Inc., as Amicus Curiae, Brulotte v. Thys Co., 379 U.S. 29 (1964).

${ }_{13}$ Although the patent misuse doctrine has often been characterized as correspondent to the equitable defense of "unclean hands," it has broader implications in terms of its concern for the public interest. The equitable defense is normally applied to situations where the plaintiff has dealt unjustly in the transaction of which he complains. In contrast, the misuse doctrine may be applicable regardless of whether the particular defendant has suffered from the patent misuse-the adverse effect upon the public interest, resulting from the plaintiff's conduct, disqualifies him to maintain the suit. See Morton Salt Co. v. G. S. Suppiger Co., 314 U.S. 488, 492-94 (1942).
} 
which extends beyond the scope of his patent monopoly.14 Typical of such proscribed activity are tie-ins, ${ }^{15}$ price fixing, ${ }^{10}$ exclusive dealerships, ${ }^{17}$ restrictions on the use of competitive products and processes, ${ }^{18}$ and discriminatory pricing. ${ }^{10}$ Most commonly, the doctrine operates to bar a patentee from maintaining an action for patent infringement, ${ }^{20}$ but it may also render unenforceable license agreements containing provisions constituting misuse..$^{21}$

The possibility that post-expiration royalty agreements would constitute patent misuse was first implied in Scott Paper Co. $v$. Marcalus Mfg. Co. ${ }^{22}$ In that case, the Supreme Court held that

any attempted reservation or continuation in the patentee or those claiming under him of the patent monopoly, after the patent expires, whatever the legal device employed, runs counter to the policy and purpose of the patent laws. ${ }^{23}$

After Scott Paper, several lower courts questioned the validity of the rule allowing post-expiration royalties, ${ }^{24}$ and in 1959 the Third Circuit specifically repudiated it in two cases. ${ }^{25}$ Despite these

\footnotetext{
${ }^{14}$ See Nordhaus, Antitrust Laws and Public Policy, 3 DuQuesne U.L. Rev. 1-2 (1964).

${ }^{26}$ See, e.g., Morton Salt Co. v. G. S. Suppiger Co., 314 U.S. 488 (1942). 1956).

${ }^{26}$ See, e.g., Newburgh Moire Co. v. Superior Moire Co., 237 F.2d 283 (3d Cir.

${ }^{17}$ See, e.g., F. C. Russell Co. v. Comfort Equip. Corp., 194 F.2d 592 (7th Cir. 1952) (dictum). This decision has been criticized in U.S. ATT'Y GEN., NATIONAL. Committee to StUdy the ANTITRUST LAws 251 (1955).

${ }^{13}$ See, e.g., National Lockwasher Co. v. George K. Garrett Co., 137 F.2d 255 (3d Cir. 1943).

${ }^{10}$ See, e.g., Hardinge Co. v. Jones \& Laughlin Steel Corp., 164 F. Supp. 75 (W.D. Pa. 1958).

${ }^{20}$ See, e.g., Morton Salt Co. v. G. S. Suppiger Co., 314 U.S. 488 (1942). In the absence of misuse by the patentee the patent infringer may be subject to civil action for damages and injunction. Patent Code of 1952, $\$ \$ 283-84,35$ U.S.C. $\$ \S 283-84$ (1964).

${ }^{21}$ See, e.g., Radio Corp. of America v. Lord, 28 F.2d 257 (3d Cir. 1928).

22326 U.S. 249 (1945), 59 HARv. L. REv. 299.

23326 U.S. at 256 . (Emphasis added.)

${ }^{24}$ See, e.g., Baker-Cammack Hosiery Mills v. Davis Co., 181 F.2d 550, 573 (4th Cir. 1950); Warner-Lambert Pharmaceutical Co. v. John J. Reynolds, Inc., 178 F. Supp. 655, 663-65 (S.D.N.Y. 1959); April Prods. Inc. v. G. Schirmer, Inc., 308 N.Y. 366, 373, 126 N.E.2d 283, 287 (1955).

${ }^{26}$ Ar-Tik Systems, Inc. v. Dairy Queen, Inc., 302 F.2d 496 (3d Cir. 1962), 31 GeO. WhsH. L. REv. 535; American Securit Co. v. Shatterproof Glass Corp., 268 F.2d 769 (3d Cir.), cert. denied, 361 U.S. 902 (1959). In American Securit, a license agrecment was held invalid where a licensee was compelled to take a license for a package of patents rather than for the single patent actually needed and used. Apart from the mandatory package consideration, the court concluded that such an agreement constituted patent misuse "for it extends the payment of royalties [for]... patents which may expire to the expiration date of [the last patent granted]..." $268 \mathrm{~F} .2 \mathrm{~d}$ at
} 
decisions, however, some conjecture persisted that a post expiration royalty agreement might be justifiable as a convenient method of payment if it was for a fixed and reasonable, rather than indefinite term. ${ }^{26}$ Although Brulotte appears to have decided that question, it has left in its wake several unresolved questions of importance to a patentee.

First, the extent to which patent misuse will constitute an antitrust violation is left undefined by Brulotte. ${ }^{27}$ Although both misuse and antitrust violation were argued extensively by the parties, ${ }^{28}$ the Court used neither term in its decision. Rather, the use of postexpiration royalty agreements was characterized as unlawful per se.29 However, it analogized such use to the tie-in cases, ${ }^{30}$ many of which involve findings of antitrust violations. ${ }^{31}$ For this reason, Brulotte seems to have left post-expiration royalty agreements vulnerable to private antitrust actions, given the litigious incentive of treble damages awarded in civil antitrust suits. ${ }^{32}$

Brulotte also raises the question of which post-expiration pay-

777. The $A r$-Tik case similarly held that a license agreement which required the payment of royalties "regardless of the expiration of the patent" constituted patent misuse and was unenforceable.

${ }^{20}$ See, e.g., 31 Geo. WASH. L. REv. 535,539 n.37 (1962).

27 "The legality of any attempt to bring unpatented goods within the protection of the patent is measured by the antitrust laws not by patent law." Mercoid Corp. v. Minneapolis-Honeywell Regulator Co., 320 U.S. 680, 684 (1944). From this statement arose the speculation that patent misuse must always constitute an antitrust violation. Oppenheim, Patents and Antitrust: Peaceful Coexistence?, 54 MrcH. L. REv. 199 n.1 (1955). However, the prevailing view is now to the contrary. See U.S. ATT'Y GEN., op. cit. supra note 17, at 254. See generally NordHAus AND JUROW, PATENT-ANTITRUST LAw (1961); Davis, Patent Licensing and the Anti-Trust Laws: Some Recent Developments, 46 J. PAt. OFF. Soc'y 12. (1964); Wood, Patents, Antitrust and Prima Facie Attitudes, 50 VA. L. Rev. 57 (1964).

${ }^{28}$ See Brief for Petitioners, pp. 24-28; Brief for Respondent, pp. 32-36. The United States argued only that there had been patent misuse. Brief for the United States as Amicus Curiae, pp. 6-18.

20379 U.S. at 32 . Justice Harlan's dissent construed the majority opinion as holding that Thys Co. had "unlawfully misused its patent monopoly," id. at 34, and in a footnote suggested that there existed in the record no basis for finding an antitrust violation. Id. at $38 \mathrm{n.3}$. The terminology of the majority opinion, however, is more analogous to that used in the Court's antitrust, rather than patent misuse opinions. For example, "per se" is a familiar antitrust term. U.S. ATT'Y GEN., op. cit. supra note 17, at 12. Furthermore, an antitrust violation is "unlawful" or "illegal" whereas, at least in common parlance, a finding of patent misuse is a bar to judicial relief rather than a determination of unlawfulness. See quotation note 27 supra.

${ }^{30} 379$ U.S. at 33. Compare Morton Salt Co. v. G. S. Suppiger Co., 314 U.S. 488 (1942).

${ }^{31}$ E.g., Ethyl Gasoline Corp. v. United States, 309 U.S. 436 (1940); International Business Mach. Corp. v. United States, 298 U.S. 131 (1936).

${ }^{32}$ Clayton Act $\$ 4,38$ Stat. 731 (1914), 15 U.S.C. \$15 (1964). 
ments might be recoverable if provided for in some form other than a separate licensing agreement. The United States, as amicus curiae, conceded that there would have been no misuse if the parties had agreed on a fixed price for the machines and spread that sum over seventeen annual installments, ${ }^{33}$ and the Court itself acknowledged that the sale of an unpatented machine with longterm payments based on use might be valid. ${ }^{34}$ The agreement in Brulotte, however, was too bold an "attempt to exact the same terms and conditions for the period after the patents have expired as they do for the monopoly period." 35 Thus, although long-term payments of a fixed price for a patented item, pursuant to a single contract of sale, are ostensibly enforceable, any exaction of payments based on use extending for a term beyond expiration of the patent will be unlawful "whatever the legal device employed." 36 In any event, patentees who license or sell with terms based on use will now be compelled either to periodically incorporate improvement patents into their products or to periodically restructure the terms used in their licenses or sales. ${ }^{37}$

Brulotte is clearly a manifestation of the policy announced by the Court in Scott Paper Co. that any extension of the patent monopoly beyond the expiration date of the patent will not be allowed. ${ }^{38}$ However, it would seem that the majority opinion has been unnecessarily vague in its statement of both that policy and the rule in regard to post-expiration royalties. Per se rules have the advantage of clarity of notice, but the Court has heretofore imposed such rules only when it felt that a transaction of the type involved could never be found to be reasonable.30 Read literally,

\footnotetext{
${ }^{33}$ Brief for the United States as Amicus Curiae, p. 14.

${ }^{34} 379$ U.S. at 32.

${ }^{35}$ Ibid.

${ }^{38} 379$ U.S. at 31 . The Court's concern is with the unequal leverage the patentee holds over prospective users in bargaining. A fixed-price installment contract would be more difficult to invalidate. Its form comports with the Court's concession that "a patent empowers the owner to exact royalties as high as he can negotiate with the leverage of [his] ... monopoly." Id. at 33. But post-expiration projection of payments based on use does violence to the approved form and is thus unlawful. Ibid. Scott Paper Co. v. Marcalus Mfg. Co., 326 U.S. 249, 256 (1945).

${ }^{37}$ Thus, the possible advantages of long-term payments based on use will be unavailable to those who purchase patented products near to but not after the expiration of those patents.

${ }^{88}$ See text accompanying notes 22-23 supra.

${ }^{8 \theta}$ See, e.g., Klor's Inc. v. Broadway-Hale Stores, Inc., 359 U.S. 207, 211-12 (1959); United States v. Trenton Potteries Co., 273 U.S. 392, 395.402 (1927).
} 
Brulotte could mean that many transactions which otherwise would seem reasonable will be prohibited per se. ${ }^{40}$ Although the criterion of unreasonableness may be subsequently incorporated into this rule, few patentees will risk the nonenforceability of their license agreements by relying on liberal interpretations of the decision. Thus, the ambiguity in Brulotte, so long as it remains unresolved, may greatly limit marketing methods avialable to them.

\footnotetext{
10 Long-term installment contracts for the purchase of machines containing viable patents may, for example, be embraced under the literal ambit of Brulotte. Further, purchase of machines in accordance with long-term payment provisions based on use may be advantageous to the buyer as well as the patentee.
} 